\title{
Dynamic Causality Among FDI, Economic Growth and CO2 Emissions in India With Open Markets and Technology Gap
}

\author{
Ritu Rana, National Institute of Technology, Hamirpur, India \\ Manoj Sharma, National Institute of Technology, Hamirpur, India
}

\begin{abstract}
This study examines the causality relationships between FDI, economic growth (in terms of GDP) and the natural environment, in terms of $\mathrm{CO}_{2}$ emissions and energy consumption, along with two more variables of interest i.e., trade openness and technology gap in the context of India. The data used in the study is obtained from World Development Indicators (WDI) of the World Bank Group for the period 1980 to 2014. The study employed the dynamic multivariate Toda-Yamamoto (TY) approach that uses the modified Wald (MWALD) test. The results show that FDI is neither causing economic growth nor is it bridging the technology gap directly in India. The results also indicate the existence of a Pollution Haven Hypothesis in India as the FDI is causing environmental degradation, i.e. $\mathrm{CO}_{2}$ emissions and energy consumption. Also, FDI is, though not causing GDP directly, but is doing so indirectly through $\mathrm{CO}_{2}$ emissions validating the existence of Pollution Haven Hypothesis. FDI is causing trade openness in India, but that openness is again causing more FDI which is doing no good for India.
\end{abstract}

\section{KEYWORDS}

Dynamic Causality, Economic Growth, Energy Consumption, Environmental Degradation, FDI, MWALD Test, Technology Gap, Trade Openness

\section{INTRODUCTION}

Globalisation of businesses has made economic activities cross all the boundaries. Economic activities are routed to achieve extreme economic growth. India is one among the developing countries that are framing policies to help achieve economic growth by encouraging and promoting a huge amount of business activities. At the same time, these activities become the cause of what is known as the greenhouse gas (GHG) emissions. Reducing these GHG emissions from the highly polluting emerging economies without limiting the pace of their economic development is one of the most popular debates that have attracted global attention. Four basic factors are involved in the process of economic development i.e., human and natural resources and building up of capital and technology (Hitam and Borhan, 2012). The developing countries rely mostly on the foreign capital and technology 
for their economic development. Over the last two decades, FDI flows have considerably increased all around the world (Seker et al., 2015). As per Bokpin (2017), it is largely considered that FDIs influence the economic prospects of recipient nation positively. Vu et al. (2006) also found that FDI has statistically significant positive effects on economic growth operating directly and through labor productivity. It is also considered that technology transfer provided by developed countries contributes to the productivity growth in developing countries (Xu, 2000). In the words of Borensztein et al. (1998), FDI is an important vehicle for the transfer of technology, contributing relatively more to growth than domestic investment. Although FDI is expected to increase long-run growth in the host country via technological upgrading and knowledge spillovers, the extent to which FDI is growthenhancing depends on the degree of complementarity and substitution between FDI and domestic investment (De Mello, 1999). Several relaxations in taxes, environmental standards and regulations are being provided to foreign investors to increase the level of economic activities which, ultimately, are expected to bring economic growth. Markets are thus made open to the global investors through trade liberalisation for the sake of economic growth. Hence, the idea of promoting and encouraging huge amounts of investments in business activities is considered good for any developing country like India, but there exist negative effects of such activities on the natural environment of the host country as several manufacturing processes make misuse of the natural resources. Investors from developed countries exploit the resources of developing countries as these countries have free trade policies and relaxed environmental laws. Shao (2018) found that dirty foreign investments flow to low-income countries. The reason for this he found is that in the absence of FDI-attracting factors such as infrastructure and skilled labor, low-income countries use lax environmental regulations and these low-income countries emerge as innocent pollution havens because they cannot afford the costs of implementing and monitoring environmental regulations. As per Elliot and Shimamoto (2008), there are concerns that less developed countries could competitively undercut each other's environmental regulations to attract FDI. This may result in these countries becoming "pollution havens", where multinational corporations (MNCs) locate operations in order to save on environmental related costs (Blanco et al., 2011). In this scenario, the MNCs that have more to gain from relocating are those in the most polluting intensive or "dirty" industries. India is one among those countries that strive for increase in their economic growth. For this purpose, Indian government continues to emphasize on creating favourable operating environments for both domestic and foreign investors through tax reductions/ exemptions, relaxed labour laws and natural environmental regulations, etc., but several economic activities involve highly polluting and ecologically inefficient manufacturing processes, technologies and facilities that led to environmental degradation in several forms like pollution of water bodies, toxic substances emissions, deforestation, loss of biodiversity, etc. Bokpin (2017) explained the negative effects of higher environmental degradation on the labour hours also as a result of health problems; and their consequences reduce the productive capacity. Increased economic activity is to blame for such patterns of environmental destruction. India is the fourth largest total GHG emitter in the world although it is one of the lowest per capita emitter countries (Alam et al., 2011). But still, developing countries, including India, commonly held a view that reduction in GHG emissions may constraint economic growth. Hence, investigation of causality relationships among FDI, economic growth and the natural environment becomes crucial in order to formulate strategies to cope up with the global warming and climatic instability. This paper is an attempt to study the causal relationships between these variables with a multivariate dynamic approach in Indian context.

\section{EXISTING LITERATURE AND AUTHORS' CONTRIBUTION}

\subsection{Existing Literature}

Several studies have been conducted so far to investigate the relationship between Foreign Direct Investment (FDI) and the relative improvements in the Economic Growth (EG) of the host country. 
The number of researchers and academicians who support the fact that FDI is the major driver of EG, especially in developing countries, is considerably higher than those who argue it to be untrue. It is evident in a literature review conducted by Almfraji \& Almsafir (2014). They concluded that previous studies largely prove that FDI brings positive effects on host country's EG and only in a few cases brings negative or null effects. They reviewed several factors of host country that may influence FDI-EG relationship and found that: adequate levels of human capital, well-developed financial markets and open trade regimes positively affect FDI-EG relation; dependency on foreign investments and technical gap contributes negatively; effect from income level is conflicting; and attention should be paid to the quality of political environment. To further elaborate their finding that FDI has positive effects on EG but a dependency on foreign investments may have some negative effects, it is needful here to quote the findings of Jorgenson et al. (2007). In their study of 39 less developed countries, including India, they found that less developed countries that largely depend on FDI in the manufacturing sector for their growth as compared to domestic investment, are more prone to higher per capita levels of various noxious gas emissions as compared to less dependent economies. They concluded that foreign capital has inherent motive to ignore environmental consequences for maximum profits. Thus, there arises a moderating role of good governance and quality institutions on the FDI-environment relationship as suggested by Bokpin (2017) in the African context. As per him, FDI promotion must be done in a restricted manner while keeping the environmental sustainability in consideration; and governance and institutions must be strengthened to regulate the firms' activities as the presence of quality institutions can assure the effects of FDI less harmful to the environment. Shahbaz et al. (2015) while investigating for high, middle and low-income countries also supported enforcing stringent environmental laws and providing more incentives to polluting firms for abiding legal emissions standards in low-income countries, though they included India in the middle-income panel and suggested command and control test with economic incentives for environmental regulations. Mehta (2002), in his study on the Indian mining sector, proposed Indian government to include codes of conduct that regulate and control the behaviour of large companies entering India to prevent indiscriminate exploitation of natural resources. He also advised preventing the trend of lowering the environmental standards to attract FDI. Acharyya (2009) examined the impacts of FDI on the GDP growth and $\mathrm{CO}_{2}$ emissions and found that FDI does have a positive long-run impact on GDP growth but at the same time, it also has a quite large positive impact on $\mathrm{CO}_{2}$ emissions too. It clearly signifies that as FDI increases, the EG increases and at the same time risk for natural environment increases. Baek and Koo (2008), in their study on the relationship between FDI and environment in case of China and India, also found that FDI-GDP has a positive long run relationship; and FDI- $\mathrm{SO}_{2}$ emissions too have positive long-run relationship which is mainly due to the FDI inflow of pollutionintensive industries due to the un-strict environmental regulations.

To have a look at the current state of FDI, economic growth and $\mathrm{CO}_{2}$ emissions in India, it is important to mention here that India Brand Equity Foundation (IBEF, 2018) is of the opinion that Indian government has taken many initiatives in recent years such as relaxing FDI norms across sectors such as defence, PSU oil refineries, telecom, power exchanges, and stock exchanges, among others to achieve technical know-how and generate employment. As far as the effects of FDI on economic growth is concerned, India is the second highest ranked emerging market in the top 10 in The 2018 A.T. Kearney Foreign Direct Investment Confidence Index (Kearney, 2018). If a look is taken on the effects of FDI on the environment of India, India's $\mathrm{CO}_{2}$ emissions grew by an estimated $4.6 \%$ in 2017, despite a turbulent year for its economy; and given India's early stage of economic development, low per-capita emissions and its large population, there is significant scope for its emissions to increase (Andrew, 2018).

Various theories and hypothesis have been formulated in FDI-EG-Environment debate like; Environmental Kuznets Curve (EKC) supporting the promotion of FDI for EG as growth will further contribute to solution for environmental problems (Grossman and Krueger, 1991; Shafik and Bandyopadhyay, 1992; Kuznets, 1995); Porter Hypothesis supporting FDI and stricter environmental 
regulations to form the basis for innovation resulting in the increased competitiveness of the firm; Pollution Haven Hypothesis (PHH) stating that FDI promotes the flow of polluting industries from developed countries to less developed and pollution haven countries as explained by Johnson and Turner (2010). These theories have got several supports and criticisms by academicians depending on the scope of their studies in different countries' contexts (Cole, 2004; Hitam and Borhan, 2012; Avazalipour et al., 2013).

The finance literature consists of a well debated rationale for the need of foreign investment in less developed countries due to several benefits it provides to the host country e.g. bridging the internal resource and savings gap, increasing managerial abilities, reducing foreign exchange shortage and improving balance of payment (Aliyu, 2005). One of the major benefits that FDI is considered to bring to the host country is the technology transfer (e.g. Li and Liu, 2005; Xu, 2000; and Schembri and Petit, 2009). Several studies have linked FDI with the environmental pollution on the basis of pollution haven hypothesis and have tried to find out the causal relationships among them (e.g. Seker et al., 2015; Shahbaz et al., 2015; Jorgenson et al., 2007; and Bokpin, 2017). Openness to trade i.e., trade liberalisation has also been used as a variable to examine such relationships (e.g. Choi et al., 2010). Energy consumption is considered a variable of utmost importance in the studies of causal relationships among environmental pollution and economic growth. Several studies have used energy consumption as an endogenous variable to examine such relationships (e.g. Alam et al., 2011; Choi et al., 2010; and Seker et al., 2015).

\subsection{Authors' Contribution}

Although it has been recognised that relationships among environmental pollution, foreign capital accumulation and economic growth indicators are of great importance in development theory (Xepapadeas, 2005) yet, there is no solidarity regarding the dynamic causal relationship between them in the same framework, especially for India with a dynamic multivariate approach. While FDI's effects on $\mathrm{EG}$ and $\mathrm{CO}_{2}$ emissions have been tested several times (using various causality testing techniques), there are only a few studies which evaluates the dynamic causality relationship between them along with a few other important variables like energy consumption, trade liberalisation and technology gap for India in particular. Alam et al. (2011) is one among such studies that tries to examine dynamic causal relationships between income growth, $\mathrm{CO}_{2}$ emissions and energy consumption specifically for India. The main focus of their study was, however, on examining the causal relationship between only three variables, as mentioned earlier i.e., income growth, $\mathrm{CO}_{2}$ emissions and energy consumption. Linh and Lin (2015) also tried to examine the dynamic causality relationships among $\mathrm{CO}_{2}$ emissions, energy consumption, economic growth and FDI in 12 most populous Asian countries including India, but their study did not apply the TY approach and was focused on and limited to a few variables. In this paper, the authors have tried to study a wider aspect of the causal relationship between FDI, EG, $\mathrm{CO}_{2}$ emissions and energy consumption while taking the level of trade openness and technology gap as important variables in such relationship.

The study is important for at least four reasons. First, knowledge on the effects of FDI on EG and at the same time on natural environment (symbolised by $\mathrm{CO}_{2}$ emissions and energy consumption) of India. Second, knowledge on the role of trade openness in FDI-EG-natural environment relationship (though Choi et al., 2010 used trade openness as an important variable in this relationship, still a dynamic causality testing technique was not used and it was not concerned with India specifically). Third, knowledge on the importance of technology gap in FDI-EG-natural environment relationship. This is the unique and important part of the study because the variable 'technology gap', to the best of authors' knowledge, has never ever been used in examining the FDI-EG-natural environment relationship with a dynamic multi-variate approach. Fourth, the data of recent years has been taken for the examination of such causal relationships which makes the study one of the latest in its field for India. 
This study examines the causal relationship among FDI-EG-natural environment for India with a dynamic multivariate Toda-Yamamoto (TY henceforth) approach for the period 1980-2014 (35 years).

\section{THE MODEL AND THE METHODOLOGY}

\subsection{The Model}

Initially, the study uses a linear regression model to examine the relationship between FDI, economic growth and environmental degradation in India during 1980-2014. $\mathrm{CO}_{2}$ emissions are taken as the representative of environmental degradation as $\mathrm{CO}_{2}$ emission is considered the main cause for global warming and climatic instability (IPCC, 1996) and is considered the major global pollutant. The initial model is:

$$
C O_{2}=f(G D P, F D I, O P E N, E C, T G)
$$

and the equation of the model is:

$$
\ln C O_{2_{t}}=\beta_{0}+\beta_{1}(\ln G D P)_{t}+\beta_{2}(\ln F D I)_{t}+\beta_{3}(O P E N)_{t}+\beta_{4}(\ln E C)_{t}+\beta_{5}(T G)_{t}+u_{t}
$$

where, $\mathrm{CO}_{2}$ is carbon dioxide emissions per capita (metric tons); GDP is gross domestic product per capita (current US\$); FDI is net inflows of foreign direct investment (BoP, current US\$); OPEN is a measure of trade liberalisation; $E C_{t}$ is energy consumption or energy use per capita $(\mathrm{kg}$ of oil equivalent); $T G_{t}$ is a measure of technology gap; and $u_{t}$ is the error term or the stochastic random variable; all at time $t$.

Following Choi et al. (2010), trade liberalisation at time $t$ i.e., $O P E N_{t}$ is measured as the sum of imports and exports as a percent of total GDP in a given year as follows:

$$
O P E N_{t}=I M P_{t}+E X P_{t}
$$

where, $I M P_{t}$ is imports of goods and services (\% of GDP) and $E X P_{t}$ is exports of goods and services (\% of GDP) at time $t$ and Consistent with Li and Liu (2005), technology gap is measured as follows:

$$
T G_{t}=\frac{G D P_{\text {max }_{t}}-G D P_{t}}{G D P_{t}}
$$

where, GDP max $_{t}$ is the GDP per capita (current US \$) of the United States of America (USA) at time $t$.

GDP of USA is used as $G D P_{\max }$ i.e., the highest GDP in the world because the economy of USA ranks $1^{\text {st }}$ in the world in terms of GDP as per GDP Ranking Table (World Bank Group, 2016). In the same table, the economy of India ranks $7^{\text {th }}$. Thus, there is a huge gap in the GDP of both the economies. This gap in GDP, or in final goods and services produced, is attributed to the gap in technology used in both the economies because the production and economic growth largely depends on the quality of technology involved. This measure, thus, indicates that the GDP gap in both the economies is because of the new and advanced technology used by USA which India lacks. A relative measure of technology gap has been used in the study. This gap not only affects the production outcome but also affects the environment due to several ecologically inefficient processes involved in production. Also, 
in the words of Gandolfo (1998), technology gap is the advantage enjoyed by the country that introduces new goods as a consequence of research activity and entrepreneurship, new goods are produced and the innovating country enjoys a monopoly until the other countries learn to produce these goods: in the meantime they have to import them.

\subsection{Data}

The data on all the variables used for this study (for the period 1980-2014) is sourced from one of the globally reliable sources i.e., World Development Indicators (WDI) of World Bank Group (2016) Data Reports for India. The reason behind selecting the start year as 1980 is to cover and monitor the causality relationships from at least 10 years prior to "The Liberalisation" that took place in India in the 1990s. Data is collected upto year 2014 because of the availability limitations. Also, in the end of the year 2014, the "Make in India" program was launched that raised the extent of economic activities and the resulting environmental degradation in India and such sudden increase would have given misleading results as the effects of "Make in India" programme will take years to reflect the true picture.

\subsection{The Methodology}

The main econometrics methodology used in this paper is the Modified Wald (MWALD) test proposed by Toda and Yamamoto (1995). Though there are several methodologies in the literature for testing causality such as Granger (non-) causality (Engle and Granger, 1987), Sims causality (1972) and causality in Johansen and Juselius (1990) Error Correction Mechanism (ECM), TY multivariate approach for testing the causality has its advantages over the other tests. It can be used even when the variables are integrated of different orders. It requires the estimation of an augmented Vector AutoRegression (VAR) irrespective of whether the time series is integrated or cointegrated (Ahmed, 2015). If the system has a unit root, the conventional OLS (Ordinary Least Square) of VAR in level-based Wald statistics have non-standard asymptotic distribution that may involve annoying parameters (Toda and Phillips, 1993). TY procedure put restrictions on the parameters of VAR $(l)$ from an augmented $\operatorname{VAR}\left(l+i_{\max }\right)$ model, where $l$ is the optimal lag length and $i_{\max }$ is the maximum order of integration of variables (Alam et al., 2011). The VAR $\left(l+i_{\max }\right)$ model in TY approach is written as:

$y_{t}=\alpha+\beta_{1} y_{t-1}+\ldots+\beta_{l+i_{\max }} y_{t-\left(l+i_{\max }\right)}+\varepsilon_{t}$

where $y_{t}$ consists of $K$ endogenous variables, $\alpha$ is a vector of intercept terms, $\beta$ are coefficient matrices and $\varepsilon_{\mathrm{t}}$ are white noise residuals. The null hypothesis in TY causality is based on zero restriction on first $l$ parameters $\left(H_{0}: \beta_{l}=\ldots=\beta_{l}=0\right)$ of the $k$ th element of $y_{t}$. Until $l \geq i_{\max }$, the model is valid (Kuzozumi and Yamamoto, 2000).

\subsection{The Sequencing of the Tests Performed}

At first, a graphical representation of the data series is made. Next, the appropriate maximum lag length $(l)$ for the variables has been chosen for the study. A VAR $(l)$ in levels of the data is then set up including an intercept in each equation. The residuals were then examined to see whether the VAR in levels is well specified. AR Roots Table and AR Roots Graph are used to examine the stability of the VAR model so formed, White Heteroskedasticity (No Cross Terms) test is used to examine homoskedasticity among the residuals and normality among residuals is examined with the help of J-B (Jarque-Bera) statistic through square root of correlation (Doornik-Hansen) method. Serial Correlation Lagrange's Multiplier (LM) test is used for examining serial independence among the residuals. The maximum order of integration $\left(i_{\max }\right)$ of the variables is then obtained with the help of unit root tests. All unit root tests with an optimal lag length are performed with deterministic elements 
i.e. a time trend and a constant based on the graphical representation of all the data series. The unit root tests performed in the study include Augmented Dickey Fuller (ADF) unit root test, PhillipsPerron (PP) unit root test and Kwiatkowski-Phillips-Schmidt-Shin (KPSS) unit root test for obtaining robust results. Next, Autoregressive-Distributed Lag (ARDL) Bounds test, a cointegration technique is used to determine any cointegrating equations among the variables so that an Error Correction Term (ECT) can be introduced. Finally, a levels VAR model is re-estimated with $i_{\text {max }}$ additional lags (i.e., $l+i_{\max }$ lags in total) of each of the variables into each of the equations to examine the causality among variables.

\section{RESULTS AND DISCUSSIONS}

\subsection{Graphical Representation of Data Series}

Figure 1 provides the graphical representation of all the variables of interest.

Figure 1. Graphical representation of all the data series

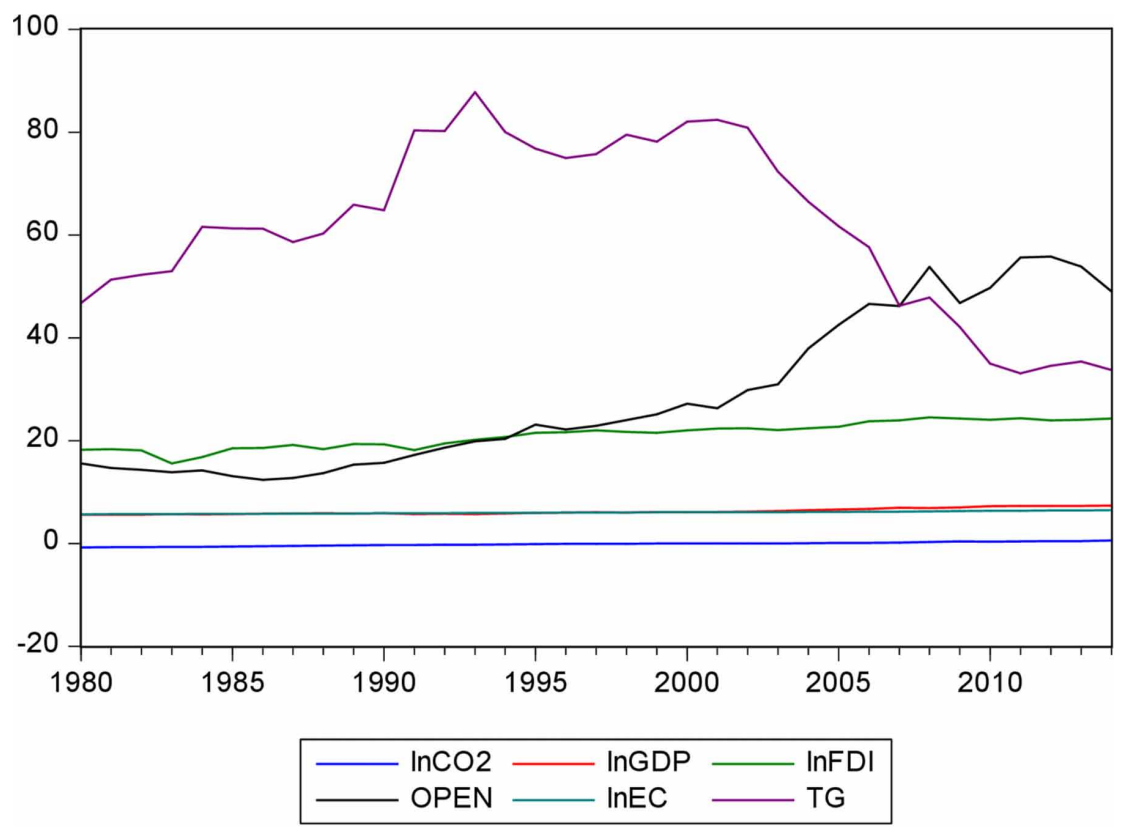

\subsection{Optimal Lag (I) Selection}

The various information criteria suggest that a maximum lag length of 2 for each variable should be used in the study (Figure 2), i.e. $l=2$.

\subsection{Residual Diagnostics of VAR (I) at Level}

A VAR (2) model in the levels of the data, including an intercept in each equation is then set up, as $l=2$ here. The residuals were then examined to make sure that the VAR is well specified. Results of the various tests performed on the residuals are shown in Table 1 and Figure 3 . The estimated model is dynamically stable as shown by the AR Roots Graph (in Figure 3) below and the information provided by the AR Roots table (in Table 1). The null hypothesis under White Heteroskedasticity (No 
Figure 2. Optimal lag selection

\begin{tabular}{ccccccc}
\hline \hline Lag & LogL & LR & FPE & AIC & SC & HQ \\
\hline \hline 0 & -120.3878 & NA & $8.55 \mathrm{e}-05$ & 7.659868 & 7.931960 & 7.751419 \\
1 & 86.19930 & 325.5312 & $2.88 \mathrm{e}-09$ & -2.678745 & $-0.774099^{*}$ & -2.037890 \\
2 & 134.5866 & $58.65129^{*}$ & $1.71 \mathrm{e}-09^{*}$ & $-3.429492^{*}$ & 0.107708 & $-2.239332^{*}$ \\
\hline \hline
\end{tabular}

* indicates lag order selected by the criterion

Table 1. Diagnosis test results of VAR (2) in levels

\begin{tabular}{|l|l|l|}
\hline \multicolumn{1}{|c|}{ Diagnostic Test } & \multicolumn{1}{|c|}{ Test Statistic } & \multicolumn{1}{c|}{ p-Value } \\
\hline VAR Stability (AR Roots Table) & No root lies outside the unit circle & - \\
\hline White Heteroskedasticity (No Cross Terms) & 513.0124 & 0.3809 \\
\hline J-B test (Doornik-Hansen) & 7.198507 & 0.8442 \\
\hline Serial Correlation LM (with $l=2$ ) & 45.37129 & 0.1361 \\
\hline
\end{tabular}

Figure 3. AR roots graph

\section{Inverse Roots of AR Characteristic Polynomial}

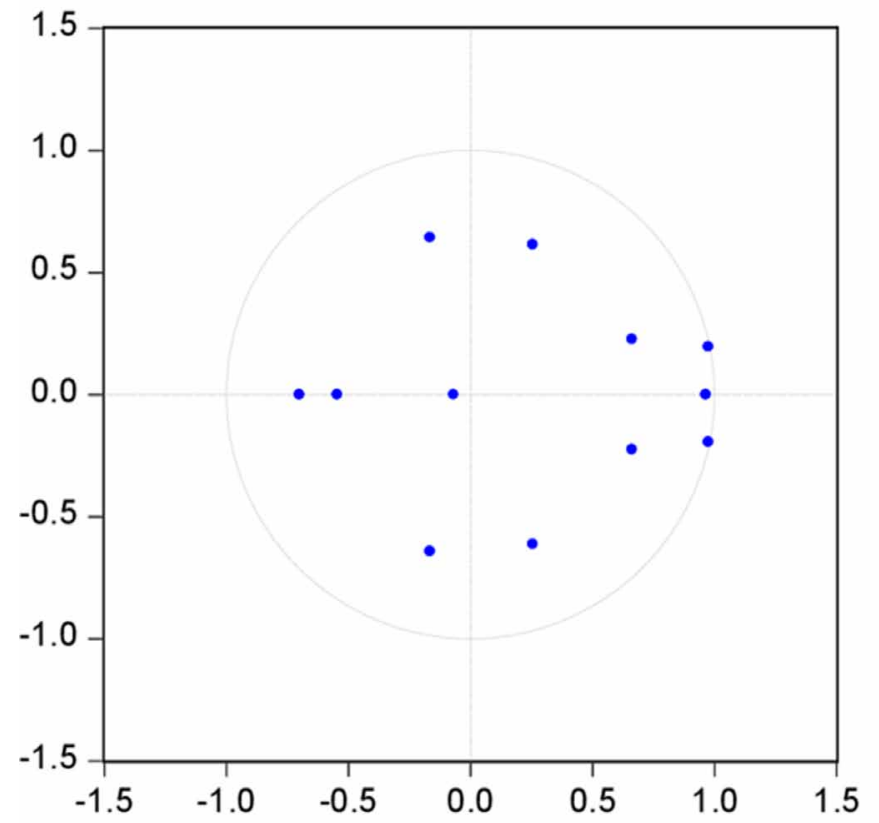

Cross Terms) is "no heteroskedasticity" which cannot be rejected in the results. The null hypothesis under J-B statistics of Square root of correlation (Doornik-Hansen) test is "residuals are multivariate normal" that too cannot be rejected in the results. Null hypothesis under Serial correlation LM test is "no serial correlation exists" that again, cannot be rejected. Thus, the residuals are found to be 
homoskedastic, normally distributed and free from serial correlation and the model is found to be stable with 2 lags. Thus, optimum lag is selected to be 2 i.e., $l=2$ in this study.

\subsection{Selection of Maximum Order of Integration ( $\left.i_{\max }\right)$ Through Unit Root Tests}

Dickey and Fuller $(1979,1981)$ devised a procedure to test for non-stationarity known as the DickeyFuller (DF) unit root test and then an Augmented Dickey Fuller (ADF) unit root test that has been used in the study to obtain maximum order of integration $\left(i_{\max }\right)$ of the variables, before estimating the TY model, along with the PP unit root test as Phillips and Perron (1988) states that ADF unit root test under rejects when the data series are subject to both: a deterministic trend and an exogenous shock that causes structural break. KPSS unit root test is also performed on the variables (to have a cross-check) for stationarity to get robust results. The null hypothesis under ADF and PP unit root test is "the variable has a unit root" i.e., the variable is non-stationary whereas, null hypothesis under KPSS unit root test is "the variable is stationary". Through the graphical representation of the data series, it becomes evident that all the series has a trend and they do not evolve around zero mean, they actually fluctuate around some other mean. Thus, deterministic elements i.e. a time trend and a constant have been included in the unit root tests. Table 2 displays the p-values of ADF, PP and KPSS unit root tests results for the data series of all the variables at levels and at first differences.

\section{Table 2. ADF, PP and KPSS unit root tests results}

\begin{tabular}{|c|c|c|c|c|c|c|c|c|c|}
\hline \multirow[b]{2}{*}{ Variable } & \multicolumn{2}{|c|}{ ADF } & \multirow{2}{*}{$\begin{array}{l}\text { Order of } \\
\text { Integration }\end{array}$} & \multicolumn{2}{|c|}{ PP } & \multirow{2}{*}{$\begin{array}{l}\text { Order of } \\
\text { Integration }\end{array}$} & \multicolumn{2}{|c|}{ KPSS } & \multirow{2}{*}{$\begin{array}{c}\text { Order of } \\
\text { Integration }\end{array}$} \\
\hline & At Level & $\begin{array}{c}\text { At First } \\
\text { Difference }\end{array}$ & & At Level & $\begin{array}{c}\text { At First } \\
\text { Difference }\end{array}$ & & At Level & $\begin{array}{c}\text { At First } \\
\text { Difference }\end{array}$ & \\
\hline $\operatorname{lnCO}_{2}$ & 0.7989 & $0.0004 * * *$ & $\mathrm{I}(1)$ & 0.7048 & $0.0004 * * *$ & $\mathrm{I}(1)$ & $0.096753^{*}$ & 0.107638 & $\mathrm{I}(1)$ \\
\hline $\operatorname{lnGDP}$ & 0.9108 & $0.0003^{* * *}$ & $\mathrm{I}(1)$ & 0.9108 & $0.0003^{* * *}$ & $\mathrm{I}(1)$ & 0.173632 & - & $\mathrm{I}(0)$ \\
\hline $\operatorname{lnFDI}$ & $0.0515^{* *}$ & - & $\mathrm{I}(0)$ & $0.0582^{*}$ & - & $\mathrm{I}(0)$ & $0.077803^{*}$ & 0.147704 & $\mathrm{I}(1)$ \\
\hline OPEN & 0.4058 & $0.0002^{* * *}$ & $\mathrm{I}(1)$ & 0.4058 & $0.0002 * * *$ & $\mathrm{I}(1)$ & 0.178056 & - & $\mathrm{I}(0)$ \\
\hline $\operatorname{lnEC}$ & 0.9948 & $0.0011^{* * * *}$ & $\mathrm{I}(1)$ & 0.9883 & $0.0009^{* * *}$ & $\mathrm{I}(1)$ & 0.154433 & - & $\mathrm{I}(0)$ \\
\hline TG & 0.8956 & $0.0002 * * *$ & $\mathrm{I}(1)$ & 0.8956 & $0.0002^{* * *} *$ & $\mathrm{I}(1)$ & 0.179570 & - & $\mathrm{I}(0)$ \\
\hline
\end{tabular}

Note: ${ }^{* * *},{ }^{* *}$ and ${ }^{*}$ indicate significance level at $1 \%, 5 \%$ and $10 \%$, respectively

The ADF unit root test results indicate that $\ln \mathrm{CO}_{2}, \ln G D P, O P E N, \ln E C$ and $T G$ are non-stationary at level but are integrated of first-order i.e. I(1) at $1 \%$ significance level whereas, $\ln F D I$ is stationary i.e. $\mathrm{I}(0)$, at $10 \%$ significance level and virtually at $5 \%$ significance level too. So, maximum order of integration as per ADF unit root test is 1 .

The PP unit root test results indicate that $\ln \mathrm{CO}_{2}, \ln G D P, O P E N, \ln E C$ and $T G$ are non-stationary at level but are integrated of first-order i.e. I(1) at $1 \%$ significance level whereas, $\ln F D I$ is stationary i.e. $\mathrm{I}(0)$, at $10 \%$ significance level. So, maximum order of integration as per PP unit root test is 1 .

The KPSS unit root test results indicate that $\ln G D P, O P E N$, $\ln E C$ and $T G$ are stationary i.e., $\mathrm{I}(0)$ but $\ln \mathrm{CO}_{2}$ and $\ln F D I$ are I(1). So, maximum order of integration as per KPSS unit root test is 1 .

Concluding all the unit root tests performed on the variables, $i_{\max }$ has been determined as 1 i.e., $i_{\max }=1$ in this study.

\subsection{ARDL Bounds Test of Cointegration}

From the results of ADF and PP unit root tests performed above, it is concluded that all the variables are integrated of first order i.e., I(1) except $\operatorname{lnFDI}$ which is stationary i.e., I(0) but none is found to be integrated of second order i.e., I(2). KPSS unit root test also indicated that the variables are 
either I(0) or I(1) but neither is I(2). In this condition, ARDL bounds testing methodology of Pesaran and Shin (1999) and Pesaran et al. (2001) is preferred to test for any cointegrating equation among variables. This technique is preferred above Johansen (1988) cointegration technique because Johansen cointegration technique can be applied only when all the variables are integrated of same order i.e., $\mathrm{I}(1)$ but ARDL bounds testing technique can be used with a mixture of $\mathrm{I}(0)$ and $\mathrm{I}(1)$ data. A general ARDL model is written as follows:

$$
\Delta Y_{t}=\beta_{0}+\sum_{i=1}^{k} \beta_{i} \Delta y_{t-i}+\sum_{i=0}^{k} \delta_{i} x_{t-i}+\varphi_{1} y_{t-1}+\varphi_{2} x_{t-1}+\mu_{t}
$$

where $\beta_{i}$ and $\delta_{i}$ are short-run coefficients; $\varphi_{1}$ and $\varphi_{2}$ are ARDL long-run coefficients; $\mu_{\mathrm{t}}$ is the disturbance term and $k$ is the number of lags.

An ARDL model of lag 1 was set up which was found to be dynamically stable (Figure 4 based on Recursive Estimates, CUSUM test) and free from autocorrelation (Serial Correlation

\section{Figure 4. CUSUM test for model stability}

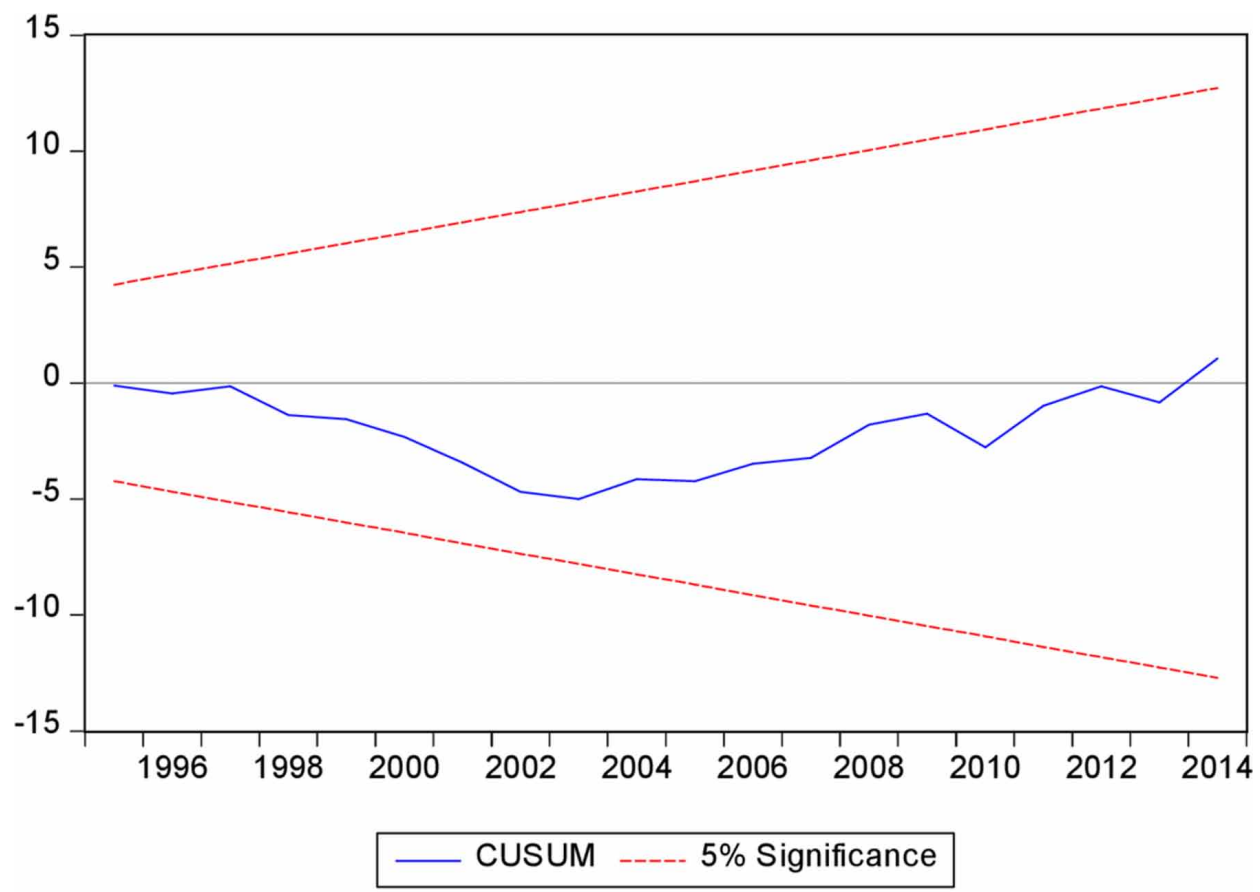

LM test's $p$-value $=0.1791$ ) but the Wald test for coefficient restrictions showed the F-statistic of 2.202614 which is lesser than the lower bound value of Pesaran's Table at 5\% critical value. Hence, the null hypothesis of "no cointegration" cannot be rejected. Thus, there was no cointegration found among variables (and hence, no ECT will be introduced), but as per Giles (2011), cointegration result does not affect the final results of the causality analysis under TY multivariate approach. 


\subsection{Granger Causality}

Finally, a VAR model in levels is then set up again but with 1 additional lag (i.e., $l+i_{\max }=2+1=3$ lags) of each of the variables into each of the equations this time as $i_{\max }$ is 1 . The lag interval for the endogenous variables is left to be at 1 to 2 , and the extra (3rd) lag of each variable is declared to be an exogenous variable. The model in Equation (5) can be written in six different equations i.e. for all the six variables under consideration e.g. for the variable $\ln \mathrm{CO}_{2}$, the equation can be written as follows:

$$
\begin{aligned}
\ln C O_{\left(2_{t}\right)}=\alpha_{1} & +\sum_{i=1}^{l} \beta_{1 i} \ln C O_{2_{t}}+\sum_{j=l+1}^{i_{\text {max }}} \beta_{2 i} \ln C O_{2_{t-j}}+\sum_{i=1}^{l} \gamma_{1 i} \ln G D P_{t}+\sum_{j=l+1}^{i_{\text {max }}} \gamma_{2 i} \ln G D P_{t-j} \\
& +\sum_{i=1}^{l} \delta_{1 i} \ln F D I_{t}+\sum_{j=l+1}^{i_{\text {max }}} \delta_{2 i} \ln F D I_{t-j}+\sum_{i=1}^{l} \varphi_{1 i} O P E N_{t}+\sum_{j=l+1}^{i_{\max }} \varphi_{2 i} O P E N_{t-j} \\
& +\sum_{i=1}^{l} \vartheta_{1 i} \ln E C_{t}+\sum_{j=l+1}^{i_{\max }} \vartheta_{2 i} \ln E C_{t-j}+\sum_{i=1}^{l} \rho_{1 i} T G_{t}+\sum_{j=l+1}^{i_{\max }} \rho_{2 i} T G_{t-j}+\epsilon_{t}
\end{aligned}
$$

Similarly, the other five different equations can be written for all the five remaining variables under consideration. In the words of Giles (2011), the coefficients of extra lags will not be included when the subsequent Wald tests are conducted. If the lag interval would have been specified to be from 1 to 3, then the coefficients of all three lags would have been included in the Wald tests, and this would have been incorrect as the Wald test statistic would not have had its usual asymptotic chisquare null distribution. Granger (non-) causality is then tested using a standard Wald test with the hypothesis that the coefficients of (only) the first $l$ lagged values of variables are zero in the equations of the other variables. It is important to note that the Wald test statistics will be asymptotically chisquare distributed with 2 degrees of freedom under the null and the extra lag that was introduced by adding $i_{\max }$ to $l$, is not included in the test results. Rejection of the null implies a rejection of Granger (non-) causality i.e., a rejection supports the presence of Granger causality.

The results of the Granger (non-) causality test are shown in Table 3 and Figures 5 and 6. Table 3 provides the chi-square stats information with their corresponding $\mathrm{p}$-values in parentheses. To help understand clearly the results of causality relationships found among all the variables, a diagram in

\begin{tabular}{|c|c|c|c|c|c|c|c|}
\hline \multirow{2}{*}{$\begin{array}{c}\text { Dependent } \\
\text { Variable }\end{array}$} & \multicolumn{6}{|c|}{ MWALD Test } & \multirow{2}{*}{$\begin{array}{l}\text { Causality } \\
\text { Inference }\end{array}$} \\
\hline & $\operatorname{lnCO}_{2}$ & InGDP & InFDI & OPEN & $\ln E C$ & TG & \\
\hline $\operatorname{lnCO}{ }_{2}$ & - & $\begin{array}{l}2.935485 \\
(0.2304)\end{array}$ & $\begin{array}{l}5.100266 \\
(0.0781)^{*}\end{array}$ & $\begin{array}{l}0.176559 \\
(0.9155)\end{array}$ & $\begin{array}{l}3.418096 \\
(0.1810)\end{array}$ & $\begin{array}{l}4.003435 \\
(0.1351)\end{array}$ & $\mathrm{CO}_{2} \leftarrow \mathrm{FDI}$ \\
\hline $\operatorname{lnGDP}$ & $\begin{array}{l}5.169558 \\
(0.0754)^{*}\end{array}$ & - & $\begin{array}{l}3.399969 \\
(0.1827)\end{array}$ & $\begin{array}{l}1.602100 \\
(0.4489)\end{array}$ & $\begin{array}{l}0.992909 \\
(0.6087)\end{array}$ & $\begin{array}{l}1.781919 \\
(0.4103)\end{array}$ & $\mathrm{GDP} \leftarrow \mathrm{CO}_{2}$ \\
\hline $\operatorname{lnFDI}$ & $\begin{array}{l}4.213923 \\
(0.1216)\end{array}$ & $\begin{array}{l}7.838256 \\
(0.0199)^{* *}\end{array}$ & - & $\begin{array}{l}6.829382 \\
(0.0329)^{* *}\end{array}$ & $\begin{array}{l}0.132292 \\
(0.9360)\end{array}$ & $\begin{array}{l}3.953737 \\
(0.1385)\end{array}$ & $\begin{array}{l}\mathrm{FDI} \leftarrow \mathrm{GDP} \\
\mathrm{FDI} \leftarrow \mathrm{OPEN}\end{array}$ \\
\hline OPEN & $\begin{array}{l}5.316818 \\
(0.0701)^{*}\end{array}$ & $\begin{array}{l}5.908679 \\
(0.0521)^{* *}\end{array}$ & $\begin{array}{l}5.176256 \\
(0.0752)^{*}\end{array}$ & - & $\begin{array}{l}1.592658 \\
(0.4510)\end{array}$ & $\begin{array}{l}2.079663 \\
(0.3535)\end{array}$ & $\begin{array}{l}\mathrm{OPEN} \leftarrow \mathrm{CO}_{2} \\
\mathrm{OPEN} \leftarrow \mathrm{GDP} \\
\mathrm{OPEN} \leftarrow \text { FDI }\end{array}$ \\
\hline $\operatorname{lnEC}$ & $\begin{array}{l}9.333615 \\
(0.0094)^{* * *}\end{array}$ & $\begin{array}{l}11.67809 \\
(0.0029)^{* * *}\end{array}$ & $\begin{array}{l}14.12163 \\
(0.0009)^{* * * *}\end{array}$ & $\begin{array}{l}1.767089 \\
(0.4133)\end{array}$ & - & $\begin{array}{l}17.89066 \\
(0.0001)^{* * *}\end{array}$ & $\begin{array}{l}\mathrm{EC} \leftarrow \mathrm{CO}_{2} \\
\mathrm{EC} \leftarrow \mathrm{GDP} \\
\mathrm{EC} \leftarrow \mathrm{FDI} \\
\mathrm{EC} \leftarrow \mathrm{TG}\end{array}$ \\
\hline TG & $\begin{array}{l}6.114471 \\
(0.0470)^{* *}\end{array}$ & $\begin{array}{l}1.831321 \\
(0.4003)\end{array}$ & $\begin{array}{l}3.470185 \\
(0.1764)\end{array}$ & $\begin{array}{l}1.137118 \\
(0.5663)\end{array}$ & $\begin{array}{l}0.785265 \\
(0.6753)\end{array}$ & - & $\mathrm{TG} \leftarrow \mathrm{CO}_{2}$ \\
\hline
\end{tabular}
circular form is drawn as shown in Figure 5. Similarly, Figure 6 represents the diagram of various

\section{Table 3. Granger causality results}

Note: ${ }^{* * *},{ }^{* *}$ and ${ }^{*}$ indicate significance level at $1 \%, 5 \%$ and $10 \%$, respectively; p-values are in parentheses; and $\leftarrow$ denotes a uni-directional causality 
International Journal of Asian Business and Information Management

Volume 11 • Issue 3 • July-September 2020

Figure 5. Causality relationships

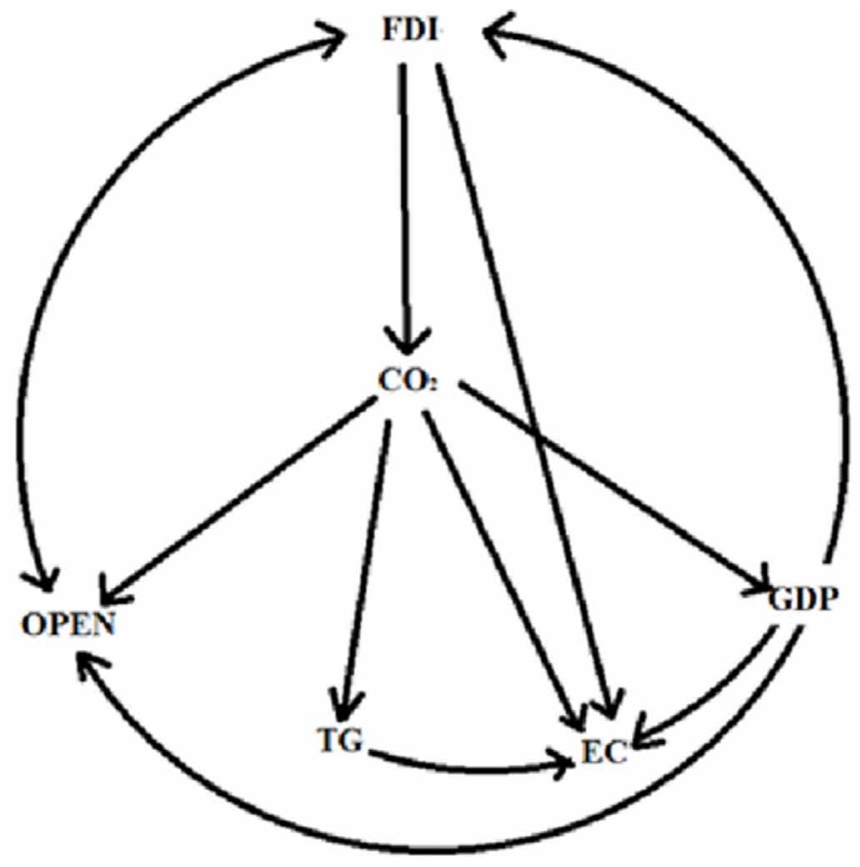

Figure 6. Inter-relationships among variables
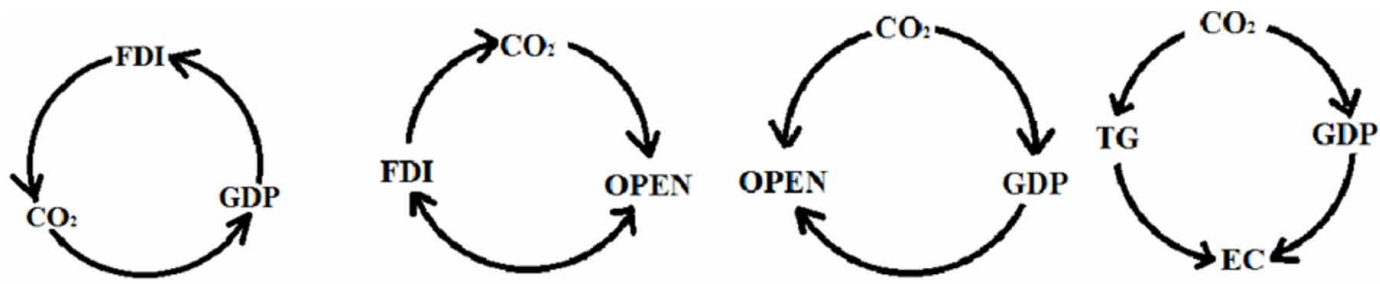

$\mathrm{i}$

ii

iii

iv

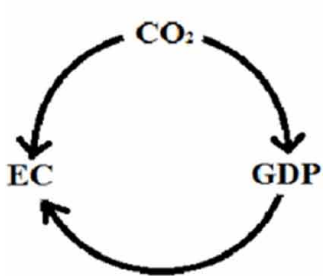

V

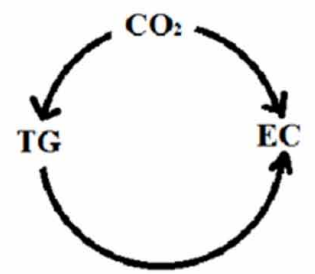

vi

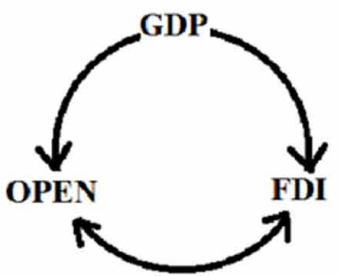

vii

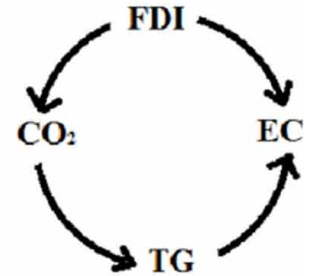

viii 
inter-relationships found among different variables. Although the main aim of the study is to examine the effects of FDI on economic growth and natural environment of India and examine the causality relationships between these three important variables only i.e., FDI, economic growth and $\mathrm{CO}_{2}$ emissions, but the study would be incomplete, or we can say, the results will not be accurate if one will not take into account other important variables that largely affect these three variables under study and not monitor the causality relationships among all of these variables. Thus, the reason behind establishing these inter-relationships among all the variables is to get an accurate and detailed causality.

\subsection{Findings in Detail}

Results in Table 4 and Figures 5 and 6 show that variables are forming several inter-linked interrelationships with other variables. The inter-relationships shown in 1, 2, and 3 (in Figure 6) are almost similar and inter-linked. Similarly, inter-relationships shown in 4, 5, and 6 are also similar and inter-linked. The explanations of these relationships are as follows:

1. $\mathrm{CO}_{2}-\mathbf{G D P}-\boldsymbol{F D I}$ : There is uni-directional causality from $\mathrm{CO}_{2}$ to GDP, which is a clear indication that the level of economic growth in India is largely caused by the degradation in the natural environment. Uni-directional causality from GDP to FDI signifies that the level of economic growth is one of the main causes of attracting foreign capital inflows in India. Finally, unidirectional causality from FDI to $\mathrm{CO}_{2}$ represents FDI as one of the causes of environmental degradation. Also, FDI is not causing GDP directly but indirectly through $\mathrm{CO}_{2}$ emissions;

2. $\mathrm{CO}_{2}-\mathrm{OPEN-FDI:} \mathrm{There} \mathrm{is} \mathrm{uni-directional} \mathrm{causality} \mathrm{from} \mathrm{CO}_{2}$ to $\mathrm{OPEN}$, which indicates that the trade liberalisation in India is largely caused by the degradation in the natural environment i.e., due to the concern about the environment India has made its markets open for free trade in the hope of receiving any new cleaner technologies. Bi-directional causality between OPEN and FDI signifies that open markets (like economic growth) are one of the main causes of attracting foreign capital inflows in India and FDI brings more trade openness in Indian markets. But again, FDI is causing environmental degradation;

3. $\mathrm{CO}_{2}-\mathbf{G D P}-\boldsymbol{O P E N}$ : Uni-directional causalities from $\mathrm{CO}_{2}$ to GDP and OPEN; and uni-directional causality from GDP to OPEN indicate that environmental degradation is driving the economic growth in India and also this economic growth is bringing openness in Indian markets;

4. $\mathrm{CO}_{2}-\boldsymbol{G D P}-\boldsymbol{T G}-\boldsymbol{E C}$ : Inter-linked uni-directional causality from $\mathrm{CO}_{2}$ to $\mathrm{GDP}$ and $\mathrm{TG}$ and ultimately from GDP and TG to EC shows that environmental degradation drives the economic growth as well as the technology gap in India (could be negatively or positively) and this level of economic growth and the gap in technology ultimately become the cause of energy consumption. $\mathrm{CO}_{2}$ is not just directly causing energy consumption but also through technology gap and income growth that it drives. This relationship can be made clear by dividing it into two parts and discussing them separately; and this is what follows next;

5. $\mathrm{CO}_{2}-\boldsymbol{G D P}-\boldsymbol{E C}$ : Environmental degradation in India is driving the level of economic growth and ultimately this economic growth becomes the cause of energy consumption, though energy consumption is not causing $\mathrm{CO}_{2}$ emissions;

6. $\boldsymbol{C O}_{2}-\boldsymbol{T G}-\boldsymbol{E C}$ : Environmental destruction makes India to look for and adopt advanced cleaner technologies in economic activities that ultimately affects the consumption of energy. This result can be seen in a sense that if technology gap is widened, it may cause more energy consumption; on the contrary, if this technology gap is shortened by newer and cleaner technological processes and techniques, there will be lesser energy consumption;

7. GDP-FDI-OPEN: Uni-directional causality from GDP to FDI and a bi-directional causality between trade openness and FDI signify that it is the level of economic growth and the open markets in India that is attracting more of FDI inflows. Also, the presence of FDI and the level of economic growth are causing trade openness in Indian markets; 
8. $\boldsymbol{F D I}-\boldsymbol{C O}_{2}-\boldsymbol{T G}-\boldsymbol{E C}$ : Let's see what FDI is bringing to India. It is evident from the results shown that there is uni-directional causality from FDI to $\mathrm{CO}_{2}$ and EC. This result indicates that FDI is one of the causes of $\mathrm{CO}_{2}$ emissions and energy consumption in India. And, as discussed earlier, $\mathrm{CO}_{2}$ emissions are forcing Indian government to minimise the technology gap because it is causing more of energy consumption.

\section{CONCLUSION AND RECOMMENDATIONS}

This study investigates dynamic Granger (non-) causality relationship mainly among FDI, economic growth and the natural environment of India while taking trade openness, energy consumption and technology gap into consideration, using a multivariate and dynamic TY approach, for the period 1980-2014.

Compared to the previous study of Alam et al. (2011) for India, in which the same dynamic multivariate TY approach has been used but for the period 1971-2006 (36 years), this study provides much wider view of the relationship among FDI-EG-natural environment by taking into account two more important variables that affect economic growth and natural environment i.e., trade openness and technology gap. Alam et al. (2011) found a bi-directional causality among $\mathrm{CO}_{2}$ emissions and energy consumption, whereas, this study shows a uni-directional causality from $\mathrm{CO}_{2}$ emissions to energy consumption. There is no causality found from energy consumption to $\mathrm{CO}_{2}$ emissions.

The results from the TY Model conclude mainly that Pollution Haven Hypothesis (PHH) does exist in case of India. The results show that India is making its markets open for free trade and FDI with the hope of increasing economic growth and reducing technology gap which ultimately will reduce the environmental degradation. But, FDI is not causing economic growth in terms of GDP directly, though it is causing GDP indirectly through $\mathrm{CO}_{2}$ emissions, validating the existence of Pollution Haven Hypothesis in India. FDI is even not bridging the technology gap, or maybe it is bridging but not in that proportion in which inflows of FDI are coming to India. FDI is also not reducing environmental degradation rather it is acting as one of the causes of $\mathrm{CO}_{2}$ emissions in India that supports the existence of Pollution Haven Hypothesis in India. Apart from being one of the causes of $\mathrm{CO}_{2}$ emissions, FDI is also causing energy consumption. Though FDI is making Indian markets open for free trade but that openness is again bringing more FDI to India and hence, this vicious circle continues to move further. Also, more openness to Indian markets may be misused by domestic dirty investors that lack advanced and cleaner technologies causing $\mathrm{CO}_{2}$ emissions; and involve themselves in dirty trade (i.e. import and export dirty goods) though increasing the level of GDP. Hence, it is recommended that regular checks and visits may be done to the sites of high polluting industries. Emission limits must be defined for the polluting industries and every effort should be made to make them comply with the rules. India should also limit its openness regarding export to and import from other countries. Import of dirty goods may be banned, if possible, or may be reduced to a certain limit. Similarly, 'exports' means excess production in the country, which in turn will use several renewable and non-renewable resources and even wastage of them causing environmental pollution. Thus, strict measures are recommended for Indian government to make a check on the foreign investment inflows because India is expecting cleaner technologies from foreign investments but is getting environmental destruction in return even after opening its markets for free trade and not even getting that level of economic growth as is expected from the foreign capital inflows. As mentioned earlier that despite the notable findings, the study used the data for all the variables up to year 2014 as per the availability, whereas the 'Make in India' program of Indian government was launched in the year 2014 that increased the amount of economic activities on a large scale. Hence its impacts (both negative and positive) on all the variables are not taken into account that may have both long and short-run effects on the economy as well as the natural environment of India. Authors may expect to take these impacts into consideration in their future studies. 


\section{REFERENCES}

Acharyya, J. (2009). FDI, Growth and the Environment: Evidence from India on $\mathrm{CO}_{2}$ Emission during the Last Two Decades. Journal of Economic Development, 34(1), 43-58. doi:10.35866/caujed.2009.34.1.003

Ahmed, S. F. (2015). Investigating the causal relationship between FDI and economic growth using TodaYamamoto Approach: Evidence from Bangladesh. ELK Asia Pacific Journal of Finance and Risk Mangement, $6(3), 35-49$.

Alam, M. J., Begum, I. A., Buysse, J., Rahman, S., \& Huylenbroeck, G. V. (2011). Dynamic Modeling of Causal Relationship between Energy Consumption, $\mathrm{CO}_{2}$ Emissions and Economic Growth in India. Renewable \& Sustainable Energy Reviews, 15(6), 3243-3251. doi:10.1016/j.rser.2011.04.029

Aliyu, M. A. (2005). Foreign Direct Investment and the Environment: Pollution Haven Hypothesis Revisited. Proceedings of the $8^{\text {th }}$ Annual Conference on Global Economic Analysis, Lubeck, Germany. Academic Press.

Almfraji, M. A., \& Almsafir, M. K. (2014). Foreign Direct Investment and Economic Growth: Literature Review from 1994 to 2012. Procedia: Social and Behavioral Sciences, 129, 206-213. doi:10.1016/j.sbspro.2014.03.668

Andrew, R. (2018). Guest Post: Why India's CO 2 Emissions Grew Strongly in 2017. Carbon Brief. Retrieved from www.carbonbrief.org

Avazalipour, M. S., Zandi, F., Saberi, R., Hakimipour, N., \& Damankeshideh, M. (2013). The Impact of FDI on Environmental Resources in Selected Countries (NON-OECD). International Journal of Research and Reviews in Applied Sciences, 17(1), 111-115.

Baek, J., \& Won, W. K. (2008). A dynamic approach to the FDI-environment nexus: the case of China and India. Proceedings of the 2008 Annual Meeting, American Agricultural Economics Association, Orlando, FL, July 27-29. Academic Press.

Blanco, L., Gonzalez, F., \& Ruiz, I. (2011). The Impact of FDI on CO2 Emissions in Latin America. Pepperdine University.

Bokpin, G. A. (2017). Foreign direct investment and environmental sustainability in Africa: The role of institutions and governance. Research in International Business and Finance, 39, 239-247. doi:10.1016/j.ribaf.2016.07.038

Borensztein, E., De Gregorio, J., \& Lee, J. W. (1998). How Does Foreign Direct Investment Affect Economic Growth? Journal of International Economics, 45(1), 115-135. doi:10.1016/S0022-1996(97)00033-0

Choi, E., Heshmati, A., \& Cho, Y. (2010). An Empirical Study of the Relationships between $\mathrm{CO}_{2}$ Emissions, Economic Growth and Openness. IZA Discussion Papers.

Cole, M. A. (2004). Trade, the pollution haven hypothesis and the environmental Kuznets curve: Examining the linkages. Ecological Economics, 48(1), 71-81. doi:10.1016/j.ecolecon.2003.09.007

De Mello, L. (1999). Foreign Direct Investment-Led Growth: Evidence from Time Series and Panel Data. Oxford Economic Papers, 51(1), 133-151. doi:10.1093/oep/51.1.133

Dickey, D. A., \& Fuller, W. A. (1979). Distribution of the Estimators for Autoregressive Time Series with a Unit Root. Journal of the American Statistical Association, 74(366), 427-431. doi:10.2307/2286348

Dickey, D. A., \& Fuller, W. A. (1981). Likelihood Ratio Statistics for Autoregressive Time Series with a Unit Root. Econometrica, 49(4), 1063. doi:10.2307/1912517

Elliott, R., \& Shimamoto, K. (2008). Are ASEAN Countries Havens for Japanese Pollution-Intensive Industry? World Economy, 31(2), 236-254. doi:10.1111/j.1467-9701.2007.01088.x

Engle, R., \& Granger, C. W. J. (1987). Cointegration and Error Correction: Representation, Estimation and Testing. Econometrica, 55(2), 251-276. doi:10.2307/1913236

19. Gandolfo, G. (1998). International Trade Theory and Policy: With 12 Tables. Springer. doi:10.1007/9783-642-61680-8

Giles, D. (2011, April 29). Testing for Granger Causality. Retrieved from http://davegiles.blogspot.in/2011/04/ testing-for-granger-causality.html 
Grossman, G. M., \& Krueger, A. B. (1991). Environmental Impacts of a North American Free Trade Agreement. NBER.

Hitam, M. B., \& Borhan, H. B. (2012). FDI, Growth and the Environment: Impact on Quality of Life in Malaysia. Procedia: Social and Behavioral Sciences, 50, 333-342. doi:10.1016/j.sbspro.2012.08.038

IBEF. (2018). Foreign Direct Investment (FDI). Retrieved from www.ibef.org

IPCC. (1996). Second Assessment on Climate Change. International Panel on Climate Change. Cambridge, UK: Cambridge University Press.

Johansen, S. (1988). Statistical Analysis of Cointegration Vectors. Journal of Economic Dynamics \& Control, 12(2), 231-254. doi:10.1016/0165-1889(88)90041-3

Johansen, S., \& Juselius, K. (1990). Maximum likelihood estimation and inference on cointegration- with applications to the demand for money. Oxford Bulletin of Economics and Statistics, 52(2), 169-210. doi:10.1111/j.1468-0084.1990.mp52002003.x

Johnson, D., \& Turner, C. (2010). International Business: Themes and Issues in the Modern Global Economy (2nd ed.). New York: Routledge. doi:10.4324/9780203861615

Jorgenson, A. K., Dick, C., \& Mahutga, M. C. (2007). Foreign Investment Dependence and the Environment: An Ecostructural Approach. Society for the Study of Social , 54(3), 371-394.

Kearny, A. T. (2018). The 2018 A.T. Kearney Foreign Direct Investment Confidence Index. Retrieved from www.atkearney.com

Kuznets, S. (1995). Economic Growth and Income Inequality. The American Economic Review, 45, 1-28.

Kuzozumi, E., \& Yamamoto, T. (2000). Modified lag augmented autoregressions. Econometric Reviews, 19(2), 207-231. doi:10.1080/07474930008800468

Li, X., \& Liu, X. (2005). Foreign Direct Investment and Economic Growth: An Increasingly Endogenous Relationship. World Development, 33(3), 393-407. doi:10.1016/j.worlddev.2004.11.001

Linh, D. H., \& Lin, S. M. (2015). Dynamic Causal Relationships Among $\mathrm{CO}_{2}$ Emissions, Energy Consumption, Economic Growth and FDI in the Most Populous Asian Countries. Advances in Management and Applied Economics, 5, 69-88.

Mehta, P. S. (2002). The Indian Mining Sector: Effects on the Environment \& FDI Inflows. CCNM Global Forum on International Investment Conference on Foreign Direct investment and the Environment, Paris, France, 7-8 Feb.

Pesaran, M. H., \& Shin, Y. (1999). An autoregressive distributed lag modelling approach to cointegration analysis. In S. Strom (Ed.), Econometrics and Economic Theory in the 20th Century: The Ragnar Frisch Centennial Symposium. Cambridge University Press, Cambridge. doi:10.1017/CCOL521633230.011

Pesaran, M. H., Shin, Y., \& Smith, R. J. (2001). Bounds testing approaches to the analysis of level relationships. Journal of Applied Econometrics, 16(3), 289-326. doi:10.1002/jae.616

Phillips, P. C. B., \& Perron, P. (1988). Testing for unit root in time series regression. Biometrika, 75(2), 335-346. doi:10.1093/biomet/75.2.335

Schembri, P., \& Petit, O. (2009). Clean technology transfers and North-South technological gap: An important issue for environmental policies. Inter Economics, 120, 109-130.

Seker, F., Ertugrul, H. M., \& Cetin, M. (2015). The Impact of Foreign Direct Investment on Environmental Quality: A Bounds Testing and Causality Analysis for Turkey. Renewable \& Sustainable Energy Reviews, 52, 347-356. doi:10.1016/j.rser.2015.07.118

Shafik, N., \& Bandyopadhyay, S. (1992). Economic growth and environmental quality: time-series and crosscountry evidence. World Bank Publications, 904.

Shahbaz, M., Nasreen, S., Abbas, F., \& Anis, O. (2015). Does Foreign Direct Investment Impede Environmental Quality in High, Middle and Low-income Countries? Energy Economics, 1-35. 
Shao, Y. (2018). Does FDI affect carbon intensity? New evidence from dynamic panel analysis. International Journal of Climate Change Strategies and Management, 10(1), 27-42. doi:10.1108/IJCCSM-03-2017-0062

Sims, C. A. (1972). Money, income and causality. The American Economic Review, 62, 540-552.

Toda, H. Y., \& Phillips, P. C. B. (1993). Vector autoregressions and causality. Econometrica, 61(6), 1367-1393. doi: $10.2307 / 2951647$

Toda, H. Y., \& Yamamoto, T. (1995). Statistical inferences in vector autoregressions with possibly integrated processes. Journal of Econometrics, 66(1-2), 225-250. doi:10.1016/0304-4076(94)01616-8

Vu, T. B., Gangnes, B., \& Noy, I. (2006). Is Foreign Direct Investment Good for Growth?: Evidence from Sectoral Analysis of China and Vietnam. University of Hawaii at Manoa, Department of Economics.

World Bank Group. (2016). World Development Indicators 2016. Retrieved from http://databank.worldbank. org $/$ data/reports.aspx ?source $=2 \&$ country $=$ IND\#

World Bank Group. (2016). Gross Domestic Product 2016. Retrieved from http://databank.worldbank.org/data/ download/GDP.pdf

Xepapadeas, A. (2005). Economic Growth and the Environment. In Handbook of Environmental Economics (Vol. 1, pp. 1219-1271). Academic Press.

Xu, B. (2000). Multinational enterprises, technology diffusion, and host country productivity growth. Journal of Development Economics, 62(2), 477-493. doi:10.1016/S0304-3878(00)00093-6

Ritu Rana is currently enrolled as a PhD Scholar in the Department of Management \& Humanities, National Institute of Technology (NIT) Hamirpur, Himachal Pradesh, India since 2016. She received her MBA (Finance and Marketing) and B.Com. (Foreign Trade) from Kurukshetra University, Kurukshetra, Haryana, India in 2006 and 2003, respectively. She has also worked with Indian Institute of Foreign Trade (IIFT), New Delhi in 2013 as a Programme Associate. She writes and presents widely on issues of Foreign Direct Investment and its impacts on the economic growth and the environment of the host country. Her current research interests are in international business, economics, and sustainable development.

Manoj Sharma is currently working as an Assistant Professor in the Department of Management \& Humanities, National Institute of Technology (NIT) Hamirpur, Himachal Pradesh, India. He received his PhD, M.Phil. (Econ.) and MBA from Himachal Pradesh University, Shimla, India. During his thirteen years of teaching and research, he has published more than twenty research papers in journals. He has also served various universities and institutions in different capacities and chaired technical sessions in national and international conferences. His areas of interest are international business, applied economics, environmental economics, service marketing, and transportation management. 